\title{
Fire tests of South African cross-laminated timber wall panels: fire ratings, charring rates, and delamination
}

S van der Westhuyzen, R Walls, N de Koker

Cross-laminated timber (CLT) is a product consisting of multiple timber layers (lamina) face-glued together to form structural wall and flooring systems. Internationally its use is growing rapidly, although its fire resistance is a topic of ongoing research. This study investigates the fire resistance of CLT wall panels manufactured locally from South African pine and eucalyptus, the most commonly used timber species for CLT in South Africa, through SANS10177-2 compliant fire tests of two $100 \mathrm{~mm}$ (33-33-33) thick CLT wall panel samples with dimensions of $0.9 \mathrm{~m} \times 0.9 \mathrm{~m}$. In addition to insulation and integrity fire resistance ratings, the study characterises the charring rate and delamination behaviour of $\mathrm{CLT}$. The recommended integrity and insulation fire resistance ratings for the $100 \mathrm{~mm}$ thick SA pine and eucalyptus CLT samples is 60 minutes and 90 minutes respectively. The average charring rate calculated for the SA pine CLT and eucalyptus CLT panels was $0.95 \mathrm{~mm} / \mathrm{min}$ and $0.76 \mathrm{~mm} / \mathrm{min}$ respectively. These values are higher than charring rates for bulk timber, due to significant delamination observed in both tests. Associated structural fire resistance rating was estimated for each CLT panel by rational design, giving structural resistance times of 29 mins and 36 mins for the SA pine and eucalyptus CLT, respectively. These times are notably smaller than the insulation and integrity fire ratings reported above, but are only relevant to load-bearing walls. As a result, the tested CLT panels can only be used in multi-storey timber buildings as non-loading bearing walls.

\section{INTRODUCTION}

\section{Background}

With notable improvements in both active and passive intervention strategies for fire safety, multi-storey timber structures are regaining popularity internationally, fuelled especially by the low carbon footprint of timber as a construction material. Material flaws, weaknesses and anisotropy of timber are generally overcome by combining multiple timber layers into laminated timber products such as glued-laminated timber (Glulam), longitudinally laminated timber (LLT), and cross-laminated timber (CLT).

CLT is a timber composite that was developed to address the inherent anisotropic nature of timber. CLT comprises timber planks arranged into layers (lamina) stacked in an alternating orthogonal pattern, which is then glued and compressed together to make a single solid timber panel (Burback et al 2017).

CLT is commonly used as wall and floor slabs in multi-storey timber buildings, but the fire resistance of CLT in these buildings remains a topic of ongoing research. Although significant international research has been conducted, it is unclear whether these studies can be applied to CLT products manufactured from timber species grown locally in South Africa (SA), in particular SA pine and eucalyptus, the most commonly used timber species for CLT in SA. With this in mind, an investigation of the fire resistance of locally produced CLT products has been carried out, the results of which are presented here.

\section{Effect of lamination}

Delamination, in which the outermost charred layer of a laminated timber composite detaches from the underlying bulk as a result of fire exposure and/ or failure of the adhesive (Johansson \& Svenningsson 2018), results in the loss of the insulation and protection provided by the charred layer to the underlying timber. The effect of this is that virgin wood is exposed to the fire, the fire reignites, and the extent of charring is increased.

\section{JOURNAL OF THE SOUTH AFRICAN INSTITUTION OF CIVIL ENGINEERING}

ISSN 1021-2019

Vol 62 No 1, March 2020, Pages 33-41, Paper 0889

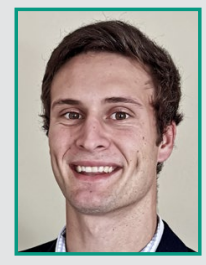

STEPHANUS (FANIE) VAN DER WESTHUYSEN is originally from the small town of Adelaide in the Eastern Cape. He graduated cum laude in 2018 from Stellenbosch University with a Bachelors degree in Civil Engineering, and is currently completing his Master's degree at Stellenbosch. His undergraduate thesis

focused on the behaviour of timber in fire, and he is now continuing this work on multi-storey timber buildings for South Africa in the university's Construction Engineering and Management Division. His current research focuses on a construction cost comparison between an eight-storey timber-frame building and a replica concrete-frame building.

Contact details

Department of Civil Engineering

Stellenbosch University

Private Bag X1, Matieland 7602, South Africa

T: +27837798367

E: 19051409@sun.ac.za / fanievdwesthuyzen@gmail.com

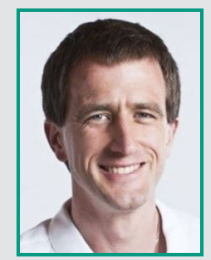

PROF RICHARD WALLS (PhD) is the head of the Fire Engineering Research Unit at Stellenbosch University (FireSUN). His research interests include informal settlement fire safety and full-scale testing, steel buildings in fire, recycled building material fire safety, fire dynamics, modelling of buildings at high temperature, and timber structures. His team is currently developing a postgraduate Master's and PhD programme in structural fire and fire safety engineering. The team also consults to industry on various fire safety topics, and is extensively involved in experimental and furnace testing work. Before joining Stellenbosch University Prof Walls worked as a consulting structural engineer in industry.

Contact details:

Department of Civil Engineering

Stellenbosch University

Private Bag X1, Matieland 7602, South Africa

T: +27218089584

E: rwalls@sun.ac.za

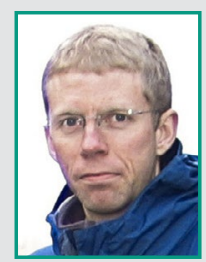

DR NICO DE KOKER is a computational physicist and structural engineer, currently working as senior lecturer in the Structura Engineering Division at Stellenbosch University. Following many years specialising in thermodynamics and heat transfer in materials at extreme conditions, he changed his focus to uncertainty quantification in engineering, completing a second PhD in reliability-based design through Stellenbosch University. His research interests broadly focus on the analysis of uncertainty in engineering calculations, and its expression in design via risk and reliability.

Contact details:

Department of Civil Engineering

Stellenbosch University

Private Bag X1, Matieland 7602, South Africa

T: +27218084434

E:ndekoker@sun.ac.za 
This will prolong the fire and cause more damage.

The type of adhesive used for bonding timber layers together varies from country to country. Polyurethane (PU)- and melamine formaldehyde (MF)-based adhesives are the most commonly used options for CLT production in Europe (Johansson \& Svenningsson 2018) and North America (Xu 2013). South Africa mainly uses one-component PU-adhesives, which has the disadvantage that it tends to perform poorly in fire (Klippel 2014). Similarly, in a recent study concluded by Lu et al (2018) it was shown that eucalyptus bonded with PU-adhesive provides poor resistance to delamination and shear.

\section{Fire behaviour}

In order to investigate the fire resistance of locally produced CLT it is necessary to provide an overview regarding timber and CLT in fire.

\section{Timber in fire}

Following an initial heating phase in timber exposed to fire, a process of thermal degradation known as pyrolysis starts to take place at about $260-300^{\circ} \mathrm{C}$ (Frangi et al 2009), producing combustible gasses and resulting in a loss of mass of timber due to evaporation and migration of moisture (Tsantaridis 2003). Following this, a char layer - the remaining layer of burnt wood which grows in thickness as pyrolysis continues - is formed on the fire-exposed surface, as shown in Figure 1 (adapted from Buchanan 2002). The char layer acts as a natural insulator for the underlying timber, due to its low effective thermal conductivity (Lineham et al 2016).

\section{Charring of timber}

The intensity of charring is generally characterised via the charring rate $(\beta)$, describing the depth through which timber chars in a given time window. That is:

$\beta=\frac{d_{c h}}{t_{f}}$

\section{Where:}

$d_{c h}$ is the charring depth for onedimensional charring, and

$t_{f}$ is time of fire exposure.

One-dimensional charring, as expressed in Equation 1, is typically applied when a single flat surface is exposed to fire. EN 1995 assumes one-dimensional

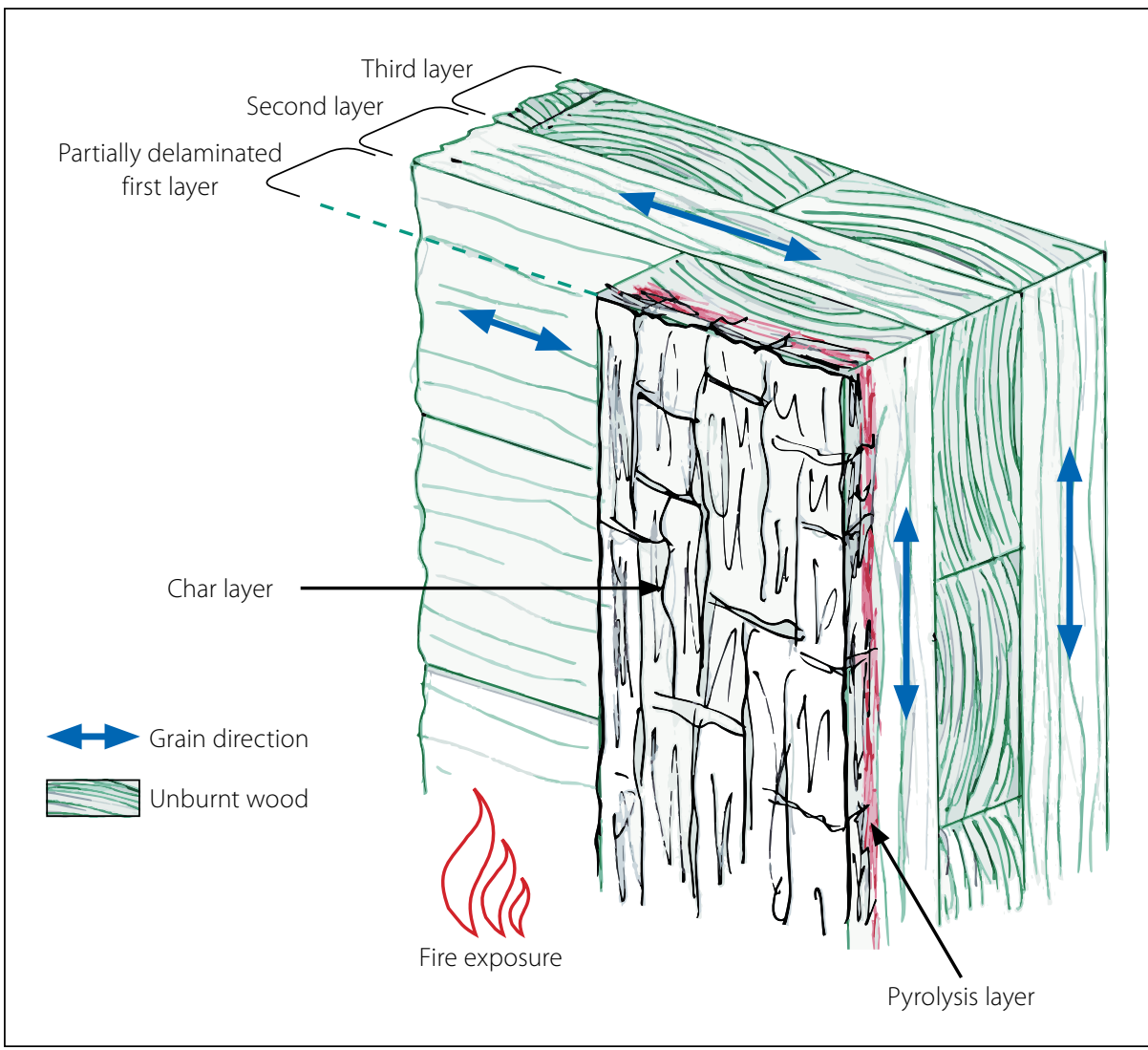

Figure 1 Cross-laminated timber wall panel exposed to fire (adapted from Buchanan (2002))

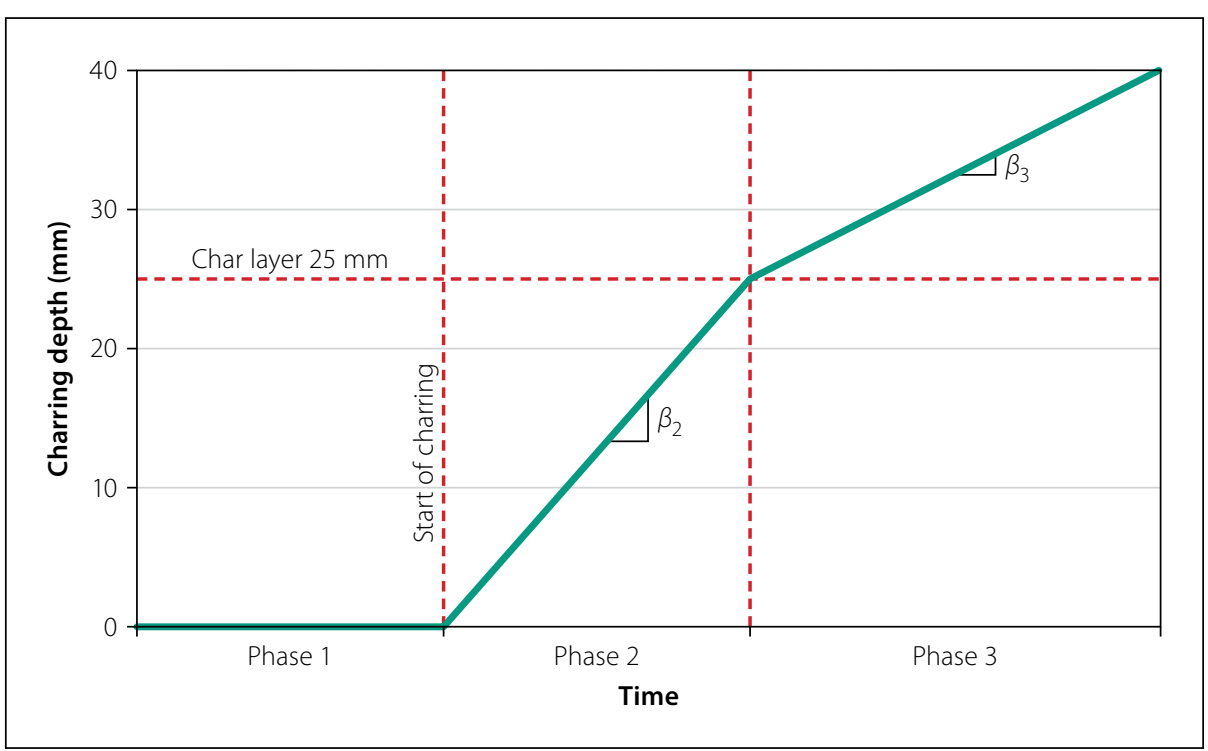

Figure 2 Charring rate model for timber proposed by Kippel and Schmid (2018)

charring to be constant with time. In the case of two-dimensional charring, at least two surfaces would have to be exposed to fire. As a result, two-dimensional charring is used to include the effects of charring rate for corners and fissures (EN 1995). Only one-dimensional charring will be considered for this specific investigation. In reality, the rate of charring does not remain constant, as it is dependent on several parameters, such as timber species, wood density, moisture content, adhesive used, cladding and the stage at which the fire is in.
Due to the slow predictable charring rate of thick timber members, a number of studies have shown that good fire ratings can be obtained by timber elements (Östman et al 2017). Although timber is combustible and experiences a reduction in cross-sectional area during a fire, the section which is not burning (the interior of the member) does not lose mechanical strength, and still provides the same resistance as before the fire. This allows heavy timber systems to maintain significant structural capacity for prolonged periods of time during fires (Dagenais et al 2013). 
Charring and delamination of CLT

In many cases the charring rate of CLT may be greater than that of solid timber, because imperfect bonds and voids between layers accelerate charring. In a recent study of charring in CLT, Klippel and Schmid (2018) noted that CLT has similar behaviour and charring rates to timber if the individual charred layers do not fall off (delaminate). However, they noted that if delamination does occur, the charring rate increases rapidly.

Based on these conclusions, Klippel and Schmid (2018) proposed a charring model similar to that adopted by EN 1995 for charring of timber with a protective layer in place (Figure 2). According to this model, charring occurs in three main phases. During Phase 1 the timber is below $300^{\circ} \mathrm{C}$ (due to outer laminae or a retardant layer), and no charring occurs (charring rate is zero). Phase 2 begins once the timber starts charring, and is characterised by a charring rate of $\beta_{2}$. Phase 3 begins when the charring layer has accumulated a sufficient thickness to slow the charring of the remaining timber to a rate of $\beta_{3}$. EN 1995 indicates that a char thickness of $25 \mathrm{~mm}$ provides enough insulation to reduce the charring rate by $50 \%$, signalling the transition from Phase 2 into Phase 3.

Delamination effectively exposes previously protected wood surfaces to the fire, increasing the charring rate and making new fuel available, with the danger of a second flashover occurring (Johansson \& Svenningsson 2018; Li et al 2016).

\section{EXPERIMENTAL SETUP}

\section{CLT test samples}

One of the main objectives of this study was to investigate the fire resistance of CLT produced locally in South Africa. The CLT test samples used in the fire test were provided by XLAM South Africa. XLAM produces CLT according to the newly proposed South African standard for performance-rated CLT, which in turn is based on the APA/ PRG 320 standard (ANSI 2017).

In order to investigate the fire resistance of CLT, two separate CLT panels were tested. Each test was conducted on a $100 \mathrm{~mm}$ thick $0.9 \mathrm{~m} \times 0.9 \mathrm{~m}$ CLT panel, made from SA pine in the first test and eucalyptus in the second. The panel thickness is that of a typical wall element produced by XLAM South Africa, consisting of three $33 \mathrm{~mm}$ thick layers of alternating grain-direction glued together with polyurethane adhesive.

Density and moisture content for the two CLT panel results for the effective density of the CLT are summarised in Table 1. Based on these values, the eucalyptus can be regarded as S7 grading, whereas the SA pine is $\mathrm{S} 5$ grading, according to the grading

\section{Table 1 Effective density of CLT panels}

\begin{tabular}{|l|c|c|}
\hline \multicolumn{1}{|c|}{ Species } & $\begin{array}{c}\text { Moisture } \\
\text { content }\end{array}$ & $\begin{array}{c}\text { Effective } \\
\text { density } \\
\mathbf{( k g / \mathbf { m } ^ { 3 } )}\end{array}$ \\
\hline SA pine CLT panel & $14.2 \%$ & 479 \\
\hline Eucalyptus CLT panel & $14.8 \%$ & 552 \\
\hline
\end{tabular}

of SANS 1783-2 (SANS 2013b). This satisfies the necessary requirements for the manufacture of CLT, although it is noted that the sampling was not done in exact accordance to SANS 1783-1 (SANS 2013a).

\section{Experimental equipment and methodology}

The experimental setup consisted of a furnace with the CLT panel built into one wall using brick and mortar, which is a standard setup for fire testing, for example also used by Johansson and Svenningsson for fire tests of Scandinavian CLT (Johansson \& Svenningsson, 2018).

\section{Furnace}

The two fire tests were conducted at the facilities of Ignis Fire Testing, using a furnace conforming to SANS 10177-2 (SANS 2005) (Figure 3). The temperature inside the furnace was regulated using a modulating gas burner to follow the standard ISO 834 fire curve, within the tolerance limits allowed by SANS 10177-2 (Figure 4). The average temperature within the furnace was measured with ten Type $\mathrm{K}$ thermocouples placed at different heights in the furnace.

\section{Thermocouple positioning}

Studies have shown that an outer char layer is observed when a temperature of $260-300^{\circ} \mathrm{C}$ is reached in timber (Yang et al 2009). The progress of the charring front can therefore be tracked using a series of thermocouples at systematically

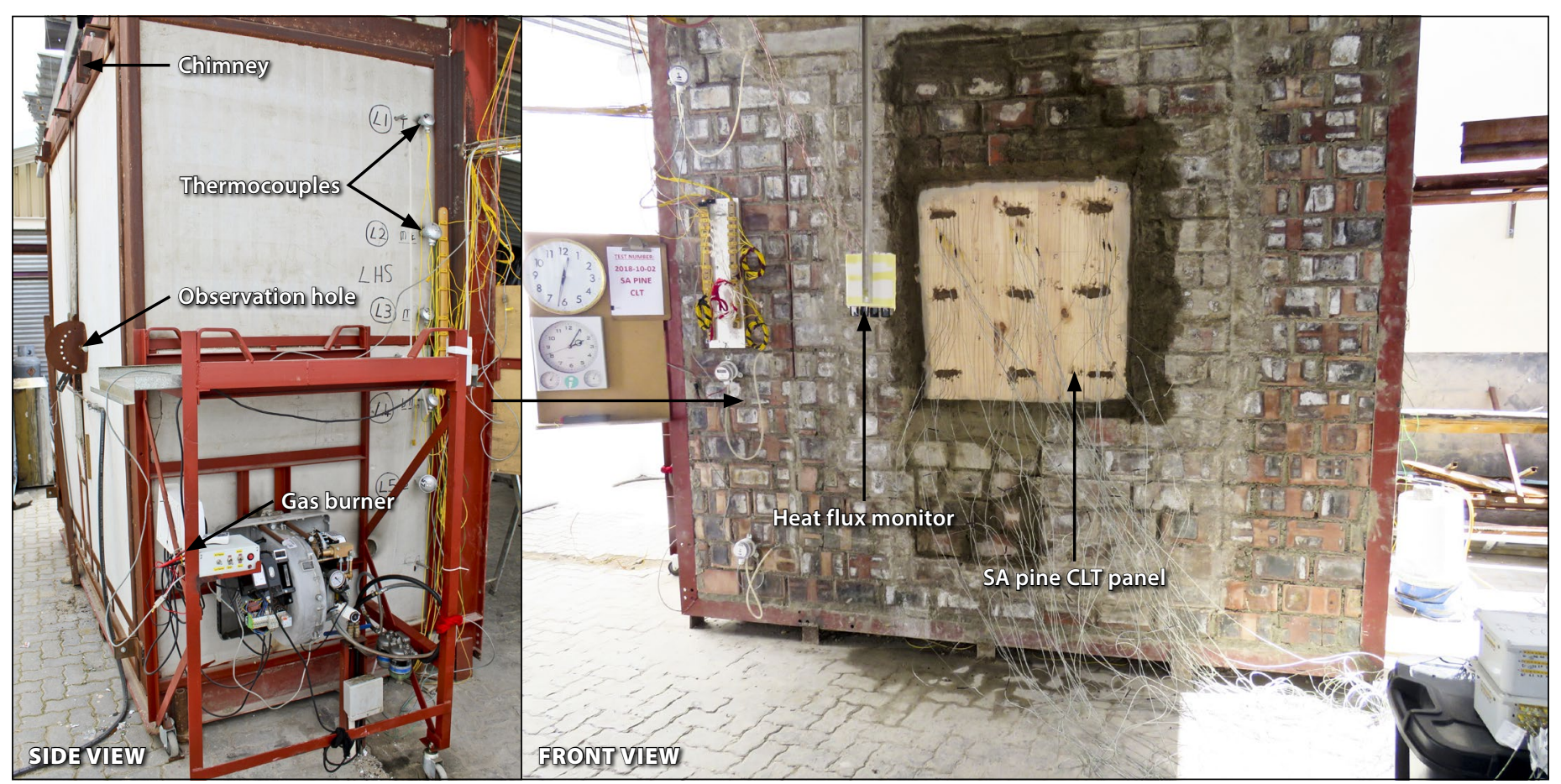

Figure 3 Ignis Fire Testing Furnace 
shallower depths (Figure 5), by identifying the progress of the reference charring temperature, $300^{\circ} \mathrm{C}$ in this case (Johansson $\&$ Svenningsson 2018). Nine sets of seven Type K thermocouples with a $2 \mathrm{~mm}$ diameter were cemented into the CLT samples at consecutive $16.5 \mathrm{~mm}$ depths, as shown in Figure 5. These depths were chosen to measure the time it takes for the charring front to reach the bond line and middle of each layer.

\section{Delamination measurement}

Observation of the progress of the test through the observation hole (Figure 3) served as the primary means of determining whether delamination had occurred. An oxygen measurement approach can also be used, although this proved ineffective due to the relative sizes of the furnace and CLT panel. A smaller furnace or a larger CLT panel may have rendered oxygen measurement more effective (Johansson \& Svenningsson 2018).

\section{Local failure}

The test was stopped once integrity failure had occurred, which was taken as the moment flames broke through the external surface of the CLT panel (i.e. the side not directly exposed to the flames inside the furnace).

\section{RESULTS AND ANALYSIS}

\section{Overall CLT sample performance}

Integrity failure times were 66 minutes and 105 minutes for the SA pine CLT and eucalyptus CLT panels, respectively. The eucalyptus CLT therefore performed significantly better than the SA pine CLT. The eucalyptus was observed to burn differently compared to the SA pine. The SA pine burned quite uniformly without any 'popping' of the timber. The eucalyptus, on the other hand, burned aggressively with small pieces of timber popping off and making significantly more noise. Additionally, the crocodile/map cracking pattern (Figure 6) of the eucalyptus was much finer than the large block cracks of the SA pine.

\section{Failure mechanism of CLT}

Both the SA pine and eucalyptus CLT panels failed as a result of the fire burning through the spacing between the vertical/horizontal planks of the respective CLT panels. The charring front had only started to enter the final layer (see below), yet the non-uniform

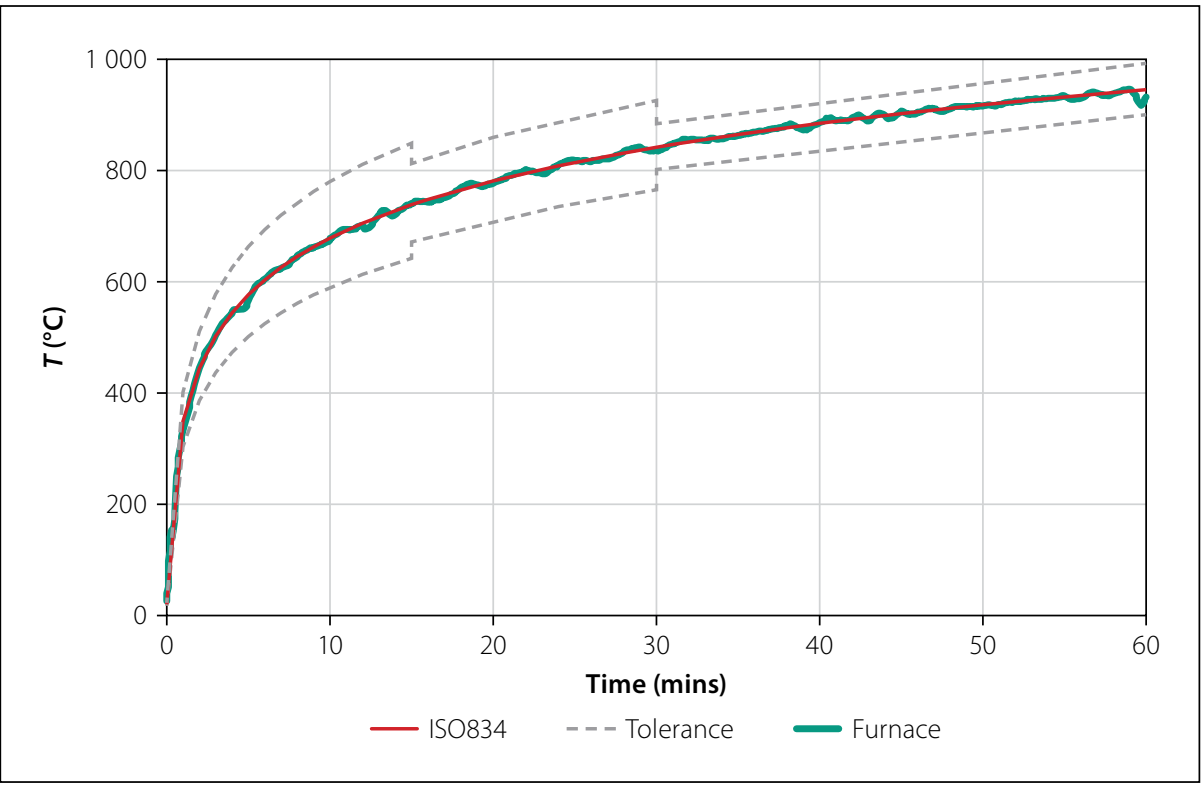

Figure 4 ISO 834 time-temperature curve for SA pine furnace test

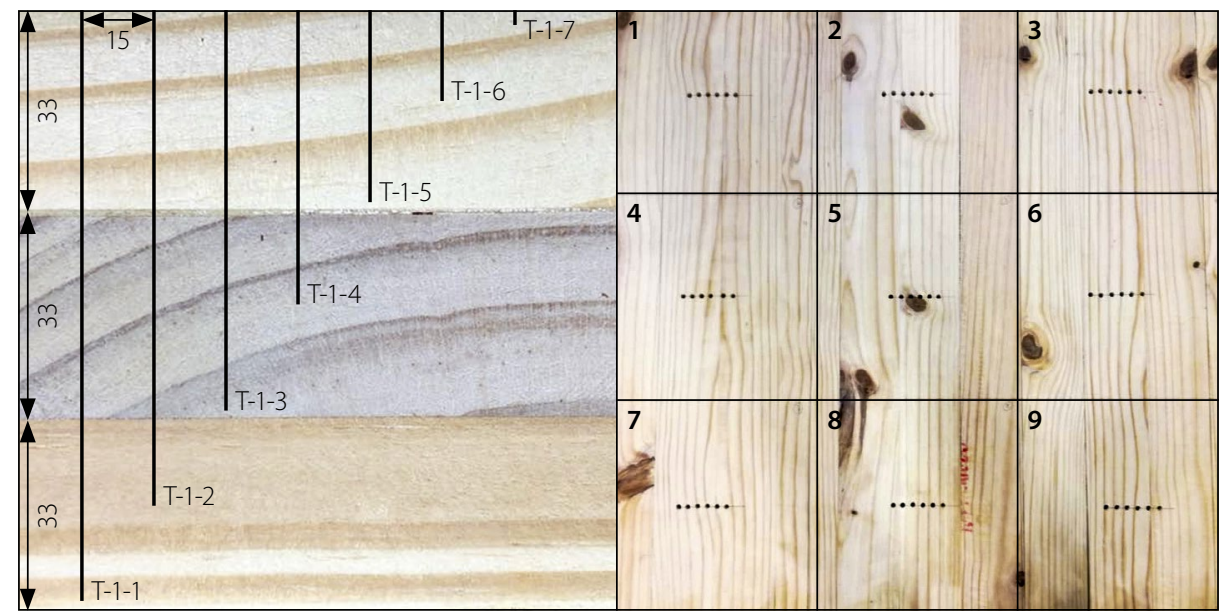

Figure 5 Cross-section of the layout of one set of thermocouples in the CLT panel (left), and thermocouple layout (right)

propagation implied for it resulted in integrity failure. As failure approached, the gaps between intra-laminar planks started widening, after which smoke started to exit through these gaps. The flames within the furnace could be seen from the outside through the gaps, and moments after the timber surface had started to darken on the outside surface, flames appeared through the gaps. Once the hole was large enough, air was sucked into the furnace via the hole, significantly increasing its growth rate.

\section{Delamination}

Delamination of both the first and second layers was clearly visible during the tests of both the SA pine and the eucalyptus CLT samples.

\section{SA Pine}

For the test of the SA pine sample, images (a) and (b) of Figure 6 clearly show how the charred remains of a timber plank had fallen off the burning surface of the panel, thus exposing the second layer of planks to the fire. Within 35 minutes of the test the second layer of the CLT became clearly visible as a result of the widening of the vertical gaps between the planks. Images (c) and (d) of Figure 6 further illustrate how the first layer delaminated. After a period of 40 minutes, more than $50 \%$ of the first layer was seen to have delaminated, with near-complete delamination of this layer observed 50 minutes into the test.

\section{Eucalyptus}

The eucalyptus sample also showed clear signs of delamination of the first and the second layer, as shown in images (e) and (f) of Figure 6. Interestingly, when comparing the two timber species, delamination occurred much later in the test for the eucalyptus, consistent with the observed lower charring rate (see below). At approximately $48 \mathrm{~min}$ the second layer became clearly 


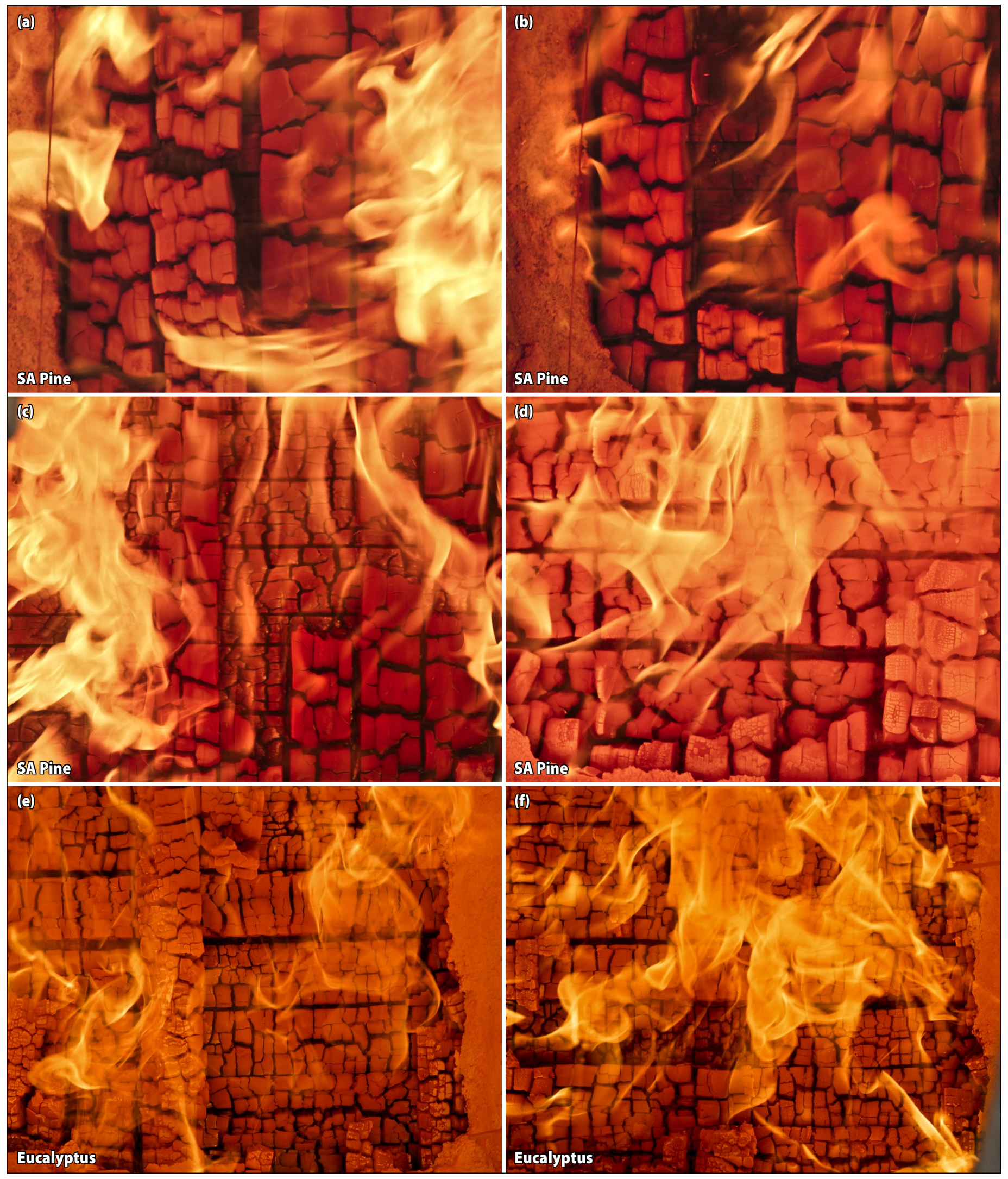

Figure 6 Images of the pine and eucalyptus samples in the furnace during the fire test, illustrating how delamination occurred

visible through the gaps in the distorted first layer, while the first signs of delamination occurred around 50 minutes into the test. Towards the end of the test, portions of the first layer were found to still be intact.

At approximately 80 minutes the third layer became visible, and delamination of the second layer started roughly $95 \mathrm{~min}$ utes into the test.

\section{Charring rate}

The progress of the charring front into the CLT panels is summarised in Figures 7 and 8. The process of inferring the progress of the charring front and determining the charring rate is illustrated in Figure 7 for point 5 and point 7 on the SA pine and eucalyptus samples, respectively (sample position numbers are as shown on
Figure 5). A temperature of $300^{\circ} \mathrm{C}$ was used as the reference temperature for charring, and the time that elapsed between the start of the test and each thermocouple reaching $300^{\circ} \mathrm{C}$ was recorded.

The gradient of a linear trend line describing the progress of the charring front (time vs depth) then gives mean and variance of the charring rate for each of the nine 


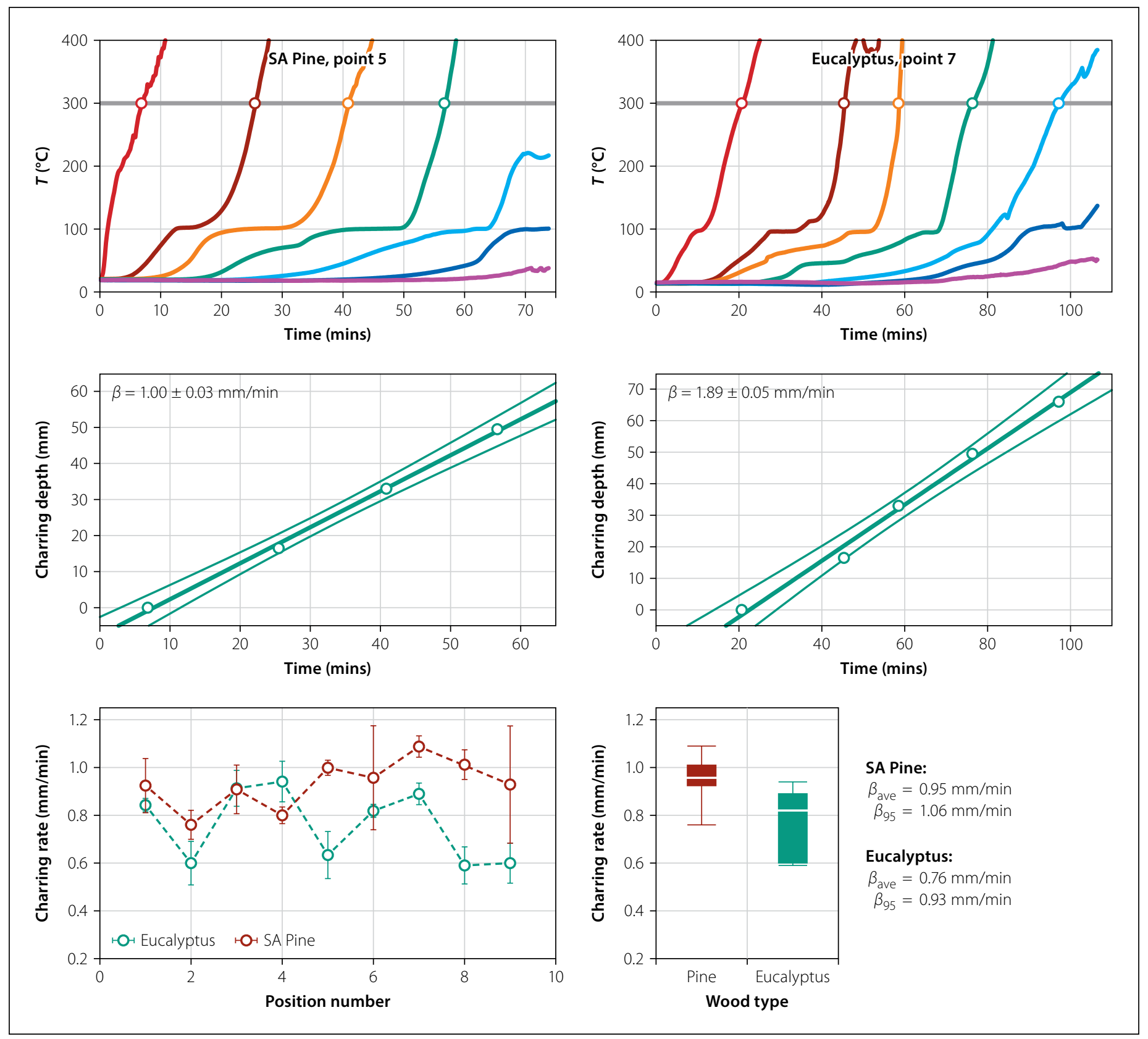

Figure 7 Eucalyptus CLT sample 7 and SA pine CLT sample 5 thermocouple readings

points on a given sample. Following this process for all nine points on each of the two panels (Figure 8), a summary of charring rates is given in the bottom two panels of Figure 7. Note also the horizontal sections of the time-temperature curves at $100^{\circ} \mathrm{C}$ in Figure 7 , which are due to the latent heat of moisture evaporating in the timber. While the charring rate is unaffected by this phenomenon, the time to initial charring will be affected by moisture content.

\section{DISCUSSION}

\section{Charring rate}

As seen in Figure 8, most of the surface of each CLT panel charred at an approximately uniform rate. Integrity failure nonetheless occurred notably earlier than would be suggested by the progress of the charring front, with the joints between intra-layer planks charring out ahead of the average front. The integrity-test failure times suggest a local effective charring rate of $1.5 \mathrm{~mm} / \mathrm{min}$ for SA pine, which is notably faster than the range of values reported in Figure 8. Careful consideration of such local effects is necessary when using charring rate in performing rational designs with CLT.

The choice of $300^{\circ} \mathrm{C}$ as the charring reference temperature may appear somewhat arbitrary. However, using a reference temperature of $260^{\circ} \mathrm{C}$ yielded almost identical average charring rates for both CLT panels. This finding is not surprising, given the rapid rise in temperature seen at any given thermocouple between $200^{\circ} \mathrm{C}$ and $350^{\circ} \mathrm{C}$ (Figure 7).
Previous fire tests carried out on European CLT panels (Klippel 2014; Stora Enso Southern Africa 2012; Teibinger \& Matzinger 2010) yielded charring rates of between $0.61-0.68 \mathrm{~mm} / \mathrm{min}$ for wall and floor elements made from CLT, i.e. values similar to that of solid timber, with Teibinger and Matzinger (2010) calculating a charring rate of $1.5 \mathrm{~mm} / \mathrm{min}$ in floor panels once delamination of the second layer had occurred. SANS 10163-1 (SANS 2003) provides a charring rate of $0.8 \mathrm{~mm} / \mathrm{min}$ for timber with an average density of $450 \mathrm{~kg} / \mathrm{m}^{3}$, whilst timber with a higher density has a charring rate of around 0.6 $\mathrm{mm} / \mathrm{min}$. Comparison of these values to the average values reported here, suggests that the observed extensive delamination resulted in an overall increase in the charring rate. A second factor could be the 

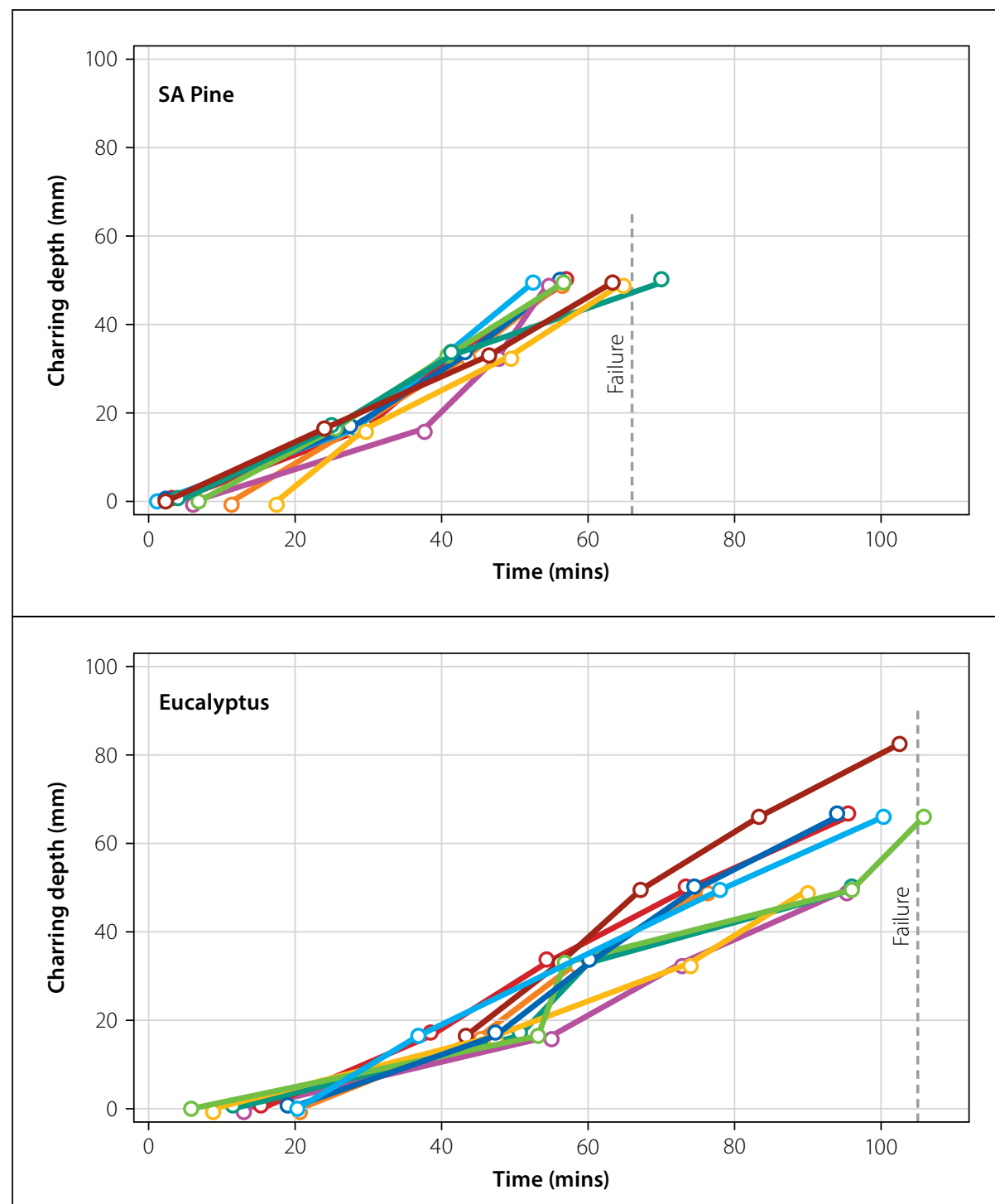

o Point 1 o Point 2 o Point 3 o Point 4 o Point 5 o Point 6 o Point 7 Point 8 o Point 9

Figure 8 Charring depth versus time for the nine pine (top) and nine eucalyptus (bottom) CLT samples at $300^{\circ} \mathrm{C}$ reference temperature

difference in timber properties - lower density timber will tend to char at a higher rate. Most of the literature on CLT charring rates covers tests performed on European or American timber species, which is typically denser than South African timber.

The notably higher observed charring rates compared to the values for solid timber (Klippel et al 2014) can be understood in terms of the model (Klippel \& Schmid 2018) discussed in the introduction (Figure 2), which predicts that the charring rate should be notably higher in the presence of delamination. The model requires a $25 \mathrm{~mm}$ thick insulation layer to form I in order to reach the lower charring rate of solid timber. In the case of this work, such a layer never forms, so that the CLT charring front always remained in Phase 2, where charring is accelerated.

\section{Integrity and insulation rating}

The three failure/acceptance criteria as expressed by SANS 10400-T for a standard fire resistance test include structural resistance (R), integrity (E) and insulation (I) (the REI symbols are not used in SANS 10400, but included below for ease of understanding). For this specific test, the failure/acceptance criteria for integrity (E) and insulation (I) were tested directly. Structural resistance can be determined using a rational design approach (Cicione \& Walls 2019), as discussed in the following section, but as was already noted above, care is required in the choice of charring rate.

In both the CLT panels considered, both integrity and insulation requirements were satisfied up to the point where integrity failure occurred. The SA pine CLT panel lasted for approximately 66 minutes before local failure, thus satisfying the requirements for a fire resistance rating of 60 minutes for insulation and integrity (EI60). The eucalyptus CLT panel lasted for approximately 105 minutes before local failure, satisfying the requirements for a fire resistance rating for insulation and integrity of 90 minutes (EI90).

The gaps that were observed forming between individual planks in the CLT layers, are seen as one of the main reasons for local failure of the CLT panels. CLT panels are typically manufactured by face-gluing individual planks to adjacent planks in the layer above. During the fire test the gap width between adjacent planks increased significantly, thus allowing a path for fire migration between adjacent planks. It may therefore be of use to investigate the effect of edge-gluing in combination with facegluing to prevent the flames from entering between adjacent planks. If the adhesive is sufficiently heat-resistant, this may delay two-dimensional charring, decreasing the overall charring rate of the CLT panel.

Note that these ratings are only relevant to CLT wall panels, as CLT floor panels will be more susceptible to delamination due to the orientation of gravity, so that the adverse effect of delamination on the integrity resistance can be expected to be more severe. Premature failure of the adhesive due to exposure to fire may also result in delamination. Future research should focus on both the type of adhesive, as well as layer thickness for the fire resistance of CLT panels.

\section{Structural resistance rating}

Figure 9 is provided to illustrate the process for the determination of rational structural resistance times for a vertically loaded $2.4 \mathrm{~m}$ high and $100 \mathrm{~mm}$ thick wall panel. The thickness of the wall panel is taken to correspond to that considered in the preceding sections, although cross-lamination is substituted with a longitudinal lamination arrangement (LLT). For a characteristic load of $100 \mathrm{kN} / \mathrm{m}$, the ambient design load is $150 \mathrm{kN} / \mathrm{m}$ while the fire limit state design load is $70 \mathrm{kN} / \mathrm{m}$ (computed using partial and combination factors specified in EN 1995. Ignoring eccentricity effects, a simple structural capacity check using one-dimensional Euler buckling (un-conservative) illustrates the loss of structural capacity (Figure 9). For charring rates corresponding to those determined in the preceding section, structural resistance times of only 29 mins 


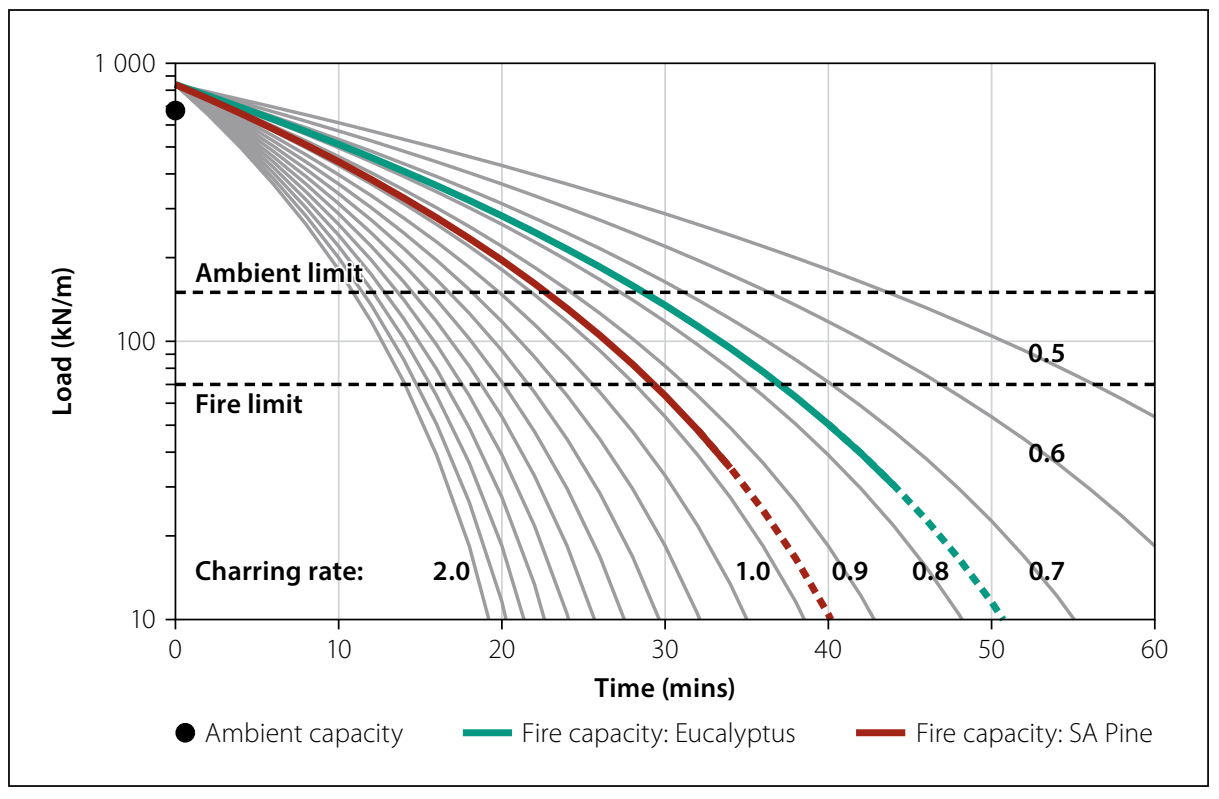

Figure 9 Deterioration of structural resistance capacity of load-bearing LLT wall panel with time

and 36 mins are obtained, notably smaller than the integrity fire ratings reported above. These resistance times will decrease further if the effect of eccentricity and of locally accelerated charring in laminated timber is taken into account (EN 1995).

This example illustrates the extent to which the integrity rating is not a good indicator of the structural rating. However, while it is desirable to perform a fire test of an element in its loaded state, this is not often practical. As an alternative, experimentally determined charring behaviour can be used in rational design for structural fire ratings by comparing the decaying resistance capacity to that required by the fire limit state.

\section{CONCLUSIONS}

The objective of the study was to determine the charring rate of CLT manufactured out of SA pine and eucalyptus, and compare these results to existing literature. A polyurethane adhesive was used for the samples, based on current local practice. The average charring rate calculated for the SA pine CLT and eucalyptus CLT panels was $0.95 \mathrm{~mm} / \mathrm{min}$ and $0.76 \mathrm{~mm} / \mathrm{min}$, respectively. These values are higher than the recommended charring rates, which range between $0.61 \mathrm{~mm} /$ $\min$ and $0.68 \mathrm{~mm} / \mathrm{min}$. This may be due to differences in physical properties, such as a higher density timber being used internationally.

The insulation and integrity fire resistance ratings of 60 and 90 minutes are very significant for the South African timber industry. Consistent with international trends, the use of timber as a construction material does not have to be limited to low-rise buildings, and could be viably extended to three- to ten-storey buildings in the context of a 90-minute rating.

Structural resistance fire ratings will be required in order to obtain regulatory support for such multi-storey structures if members are load-bearing. Loaded tests can be performed, but are often limited in their scope and geometry. Rational design for fire safety can provide insight into a broad range of structural systems (Walls et al 2014; Walls 2016), but requires that charring behaviour is well understood. Future work should focus on better characterising the localised variations in the charring, especially in the context of different adhesives and lamination geometries.

\section{ACKNOWLEDGEMENTS}

This research was financially supported by the Lloyd's Register Foundation under the Fire Engineering Education for Africa grant. The assistance of Ignis Testing, especially Dirk Streicher and Johan Swart, and the sponsoring of the fire test costs are gratefully acknowledged.

\section{REFERENCES}

ANSI (American National Standards Institure) 2017. ANSI/APA PRG 320-2017. Standard for Performance-Rated Cross-Laminated Timber. New York: ANSI.

Buchanan, A 2002. Fire performance of timber connections. Progress in Structural Engineering and Materials, 2: 278-289.
Burback, B, Pei, S \& Asce, M 2017. Cross-laminated timber for single-family residential construction : Comparative cost study. Journal of Architectural Engineering (ASCE), 23(3): 1-6.

Cicione, A \& Walls, R 2019. Estimating time to structural collapse of informal settlement dwellings based on structural fire engineering principles. In Zingoni, A. (Ed.). Advances in Engineering Materials, Structures and Systems: Innovations, Mechanics and Applications. Boca Raton, FL: CRC Press, pp 1909-1914.

Dagenais, C, White, R H \& Sumathipala, K 2013. Fire performance of cross-laminated timber assemblies, Chapter 8. In Douglas, B. (Ed.). CLT Handbook: Cross-Laminated Timber, US ed. pp 1-55. EN (European Standard) 1995. Euro Code 5. EN-1-2 2010. Design of Timber Structures, Parts 1-2: General - Structural Fire Design. [Re-issued in 2004, incorporating corrigenda June 2006 and March 2009.]

Frangi, A, Fontana, M, Hugi, E \& Jübstl, R 2009. Experimental analysis of cross-laminated timber panels in fire. Fire Safety Journal, 44(8): 1078-1087.

Johansson, E \& Svenningsson, A 2018. Delamination of cross-laminated timber and its impact on fire development. Focusing on different types of adhesives. Report 5562. Division of Fire Safety Engineering, Lund University, Sweden.

Klippel, M 2014. Fire safety of bonded structural timber elements. ETH University, Zurich, Switzerland.

Klippel, M, Leyder, C, Frangi, A et al 2014. Fire tests on loaded cross-laminated timber wall and floor elements. Fire Safety Science, 11: 626-639.

Klippel, M \& Schmid, J 2018. Design of crosslaminated timber in fire design of cross-laminated timber in fire. Structural Engineering International, 27(2): 224-230.

Li, X, McGregor, C, Medina, A, Sun, X, Barber, D \& Hadjisophocleous, G 2016. Real-scale fire tests on timber constructions. Proceedings, WCTE 2016 World Conference on Timber Engineering, 22-25 August 2016, Vienna, Austria.

Lineham, S A, Thomson, D, Bartlett, A I, Bisby, L A \& Hadden, R M 2016. Structural response of fire-exposed cross-laminated timber beams under sustained loads. Fire Safety Journal, 85: 23-34.

Lu, Z, Zhou, H, Liao, Y \& Hu, C 2018. Effects of surface treatment and adhesives on bond performance and mechanical properties of cross-laminated timber (CLT) made from small-diameter Eucalyptus timber. Construction and Building Materials, 161: 9-15.

Östman, B, Brandon, D \& Frantzich, H 2017. Fire safety engineering in timber buildings. Fire Safety Journal, 91: 11-20.

SANS (South African National Standard) 2003. SANS 10163-1:2003. The Structural Use of Timber Part 1: Limit-States Design. Pretoria: SABS Standards Division.

SANS (South African National Standard) 2005. SANS 10177-2:2005. Fire Testing of Materials, 
Components and Elements Used in Buildings. Part 2 Fire Resistance Test for Building Elements. Pretoria: SABS Standards Division.

SANS (South African National Standard) 2013a. SANS 1783-1:2013. Sawn Softwood Timber Part 1: General Requirements. Pretoria: SABS Standards Division. SANS (South African National Standard) 2013b. SANS 1783-2:2013. Sawn Softwood Timber. Part 2: Stress-Graded Structural Timber and Timber for Frame Wall Construction. Pretoria: SABS Standards Division.

Stora Enso Southern Africa 2012. CLT - Cross-

Laminated Timber Fire Protection [Brochure].
Teibinger, M \& Matzinger, I 2010. Basis for evaluation of the fire resistance of timber constructions. Final report. Vienna: Holzforschung Austria.

Tsantaridis, L 2003. Reaction to fire performance of wood and other building products. PhD Thesis, Kungliga Tekniska Högskolan, Stockholm, Sweden. Walls, R, Viljoen, C, De Clercq, H \& Retief, J 2014. A critical review on current and proposed structural fire engineering codes for steelwork in South Africa. Proceedings, International Conference on Structural Materials, ICCMATS-1, Volume 1, pp 1134-1140.

Walls, R S 2016. A beam finite element for the analysis of structures in fire. PhD Thesis, Stellenbosch
University. Available at: http://scholar.sun.ac.za/ handle/10019.1/100331.

$\mathrm{Xu}, \mathrm{S}$ 2013. A review on cross laminated timber (CLT) and its possible application in North America. BSc Report, University of British Columbia, Vancouver, Canada.

Yang, T H, Wang, S Y, Tsai, M J \& Lin, C Y 2009. The charring depth and charring rate of glued laminated timber after a standard fire exposure test. Building and Environment, 44(2): 231-236. 